\title{
IMPLEMENTASI FATWA DEWAN SYARIAH NASIONAL MAJELIS ULAMA INDONESIA (DSN-MUI) NOMOR: 92/DSN-MUI/IV/2014 TERHADAP PEMBIAYAAN PADA PRODUK RAHN (STUDI PADA PEGADAIAN SYARIAH CABANG PALU PLASA)
}

\author{
Nazil Fahmi \\ Program Studi Hukum Ekonomi Syariah IAIN Palu \\ Email: nazilfahmi1998@gmail.com \\ Nasaruddin \\ Fakultas Syariah IAIN Palu \\ Email: nas2015prudential@gmail.com \\ Fadliah Mubakkirah \\ Fakultas Syariah IAIN Palu \\ Email: mubakkirah@gmail.com
}

\begin{abstract}
This study aims to provide knowledge and understanding of the implementation of the National Sharia Council Fatwa of the Indonesian Ulema Council (DSN-MUI) Number: 92 / DSN-MUI / IV / 2014 concerning the financing of rahn products at the Pegadaian Syariah Branch Palu Plasa. This research was designed using descriptive research type, using a qualitative approach in data collection techniques. After the data is collected and passed the data analysis process, a conclusion is drawn using a deductive mindset. The results of this study indicate that the implementation reviewed in the Fatwa rules of the National Sharia Council of the Indonesian Ulema Council (DSN-MUI) Number. 92 / DSN-MUI / IV / 2014 has stipulated that the fatwa on Financing accompanied by Rahn in all forms of financing or distribution of funds of Islamic Financial Institutions (LKS) may be guaranteed with collateral (rahn) in accordance with several provisions in the fatwa. So, financing on rahn products run by Pegadaian Syariah Branch Palu Plasa has met the provisions in the fatwa.
\end{abstract}

Keywords: DSN-MUI fatwa, Pegadaian Syariah, Palu Plasa, financing, rahn products

Abstrak. Penelitian ini bertujuan untuk memberikan pengetahuan dan
pemahaman terhadap implementasi Fatwa Dewan Syariah Nasional
Majelis Ulama Indonesia (DSN-MUI) Nomor: 92/DSN-MUI/IV/2014
terhadap pembiayaan pada produk rahn di Pegadaian Syariah Cabang Palu
Plasa. Penelitian ini di desain dengan menggunakan jenis penelitian 
deskriptif, dengan menggunakan pendekatan kualitatif dalam teknik pengumpulan data. Setelah data terkumpul dan melewati proses analisis data, maka diambil kesimpulan dengan menggunakan pola pikir deduktif. Hasil penelitian ini menunjukkan bahwa impelementasi yang ditinjau pada aturan Fatwa Dewan Syariah Nasional Majelis Ulama Indonesia (DSNMUI) Nomor. 92/DSN-MUI/IV/2014 telah menetapkan bahwa fatwa tentang Pembiayaan yang Disertai Rahn dalam semua bentuk pembiayaan atau penyaluran dana Lembaga Keuangan Syariah (LKS) boleh dijamin dengan agunan (rahn) sesuai dengan beberapa ketentuan dalam fatwa tersebut. Jadi, pembiayaan pada produk rahn yang dijalankan oleh Pegadaian Syariah Cabang Palu Plasa telah memenuhi ketentuan-ketentuan dalam fatwa tersebut.

Kata kunci: Fatwa DSN-MUI, Pegadaian Syariah Cabang Palu Plasa, Pembiayaan, produk rahn

\section{Pendahuluan}

Sistem ekonomi di Indonesia berlandaskan pada Pancasila dan Undang-Undang Dasar Negara Republik Indonesia 1945 mengandung nilai yang sama dengan nilai-nilai yang terdapat pada sistem ekonomi Islam yang berlandaskan pada al-quran dan hadis Rasulullah Muhammad saw. Persamaan nilai tersebut adalah usaha untuk mencapai nilai keadilan dalam bidang ekonomi untuk setiap individu baik dengan menggunakan sistem ekonomi Indonesia yang berlandaskan Pancasila dan Undang-Undang Dasar Negara Republik Indonesia 1945 maupun dengan menggunakan sistem ekonomi Islam. Sehingga relevansi ekonomi Islam untuk diterapkan tidak perlu dipertanyakan kembali. Kemudian Indonesia telah melaksanakan praktik perekonomian dengan menggunkakan prinsip syariah. Praktik tersebut dapat dijumpai di lembaga-lembaga keuangan, baik lembaga keuangan bank maupun non bank. Misalnya, bank syariah, asuransi syaraiah dan pegadaian syariah. ${ }^{1}$

Perkembangan lembaga keuangan syariah di Indonesia merupakan tolak ukur dalam kemajuan ekonomi syariah di Indonesia. Jika dilihat dari perkembangan lembaga keuangan syariah

\footnotetext{
${ }^{1}$ Habib Wakidatul Ihtiar, Analisis Fatwa Dewan Syariah Nasional Nomor: 92/DSN-MUI/IV/2014 tentang Pembiayaan yang Disertai Rahn, vol. 03, no.1 (Tulungagung: An-nisbah, 2016). 25. http://ejournal.iaintulungagung.ac.id/index.php/nisbah/article/view/274/210. (01 Agustus 2019 ).
} 
di Indonesia, maka tidak asing lagi mendengar kalimat motto dari salah satu lembaga keuangan syariah non bank yaitu "mengatasi masalah tanpa masalah". Motto ini diidentikan dengan lembaga pegadaian syariah. Perkembangan pegadaian syariah merupakan hasil representasi dari terbitnya Peraturan Pemerintah Nomor 10 yang dikeluarkan pada tanggal 1 April 1990 dapat dikatakan menjadi tonggak awal kebangkitan Pegadaian, satu hal yang perlu dicermati bahwa Peraturan Pemerintah Nomor 10 menegaskan misi yang harus diemban oleh Pegadaian untuk mencegah praktik riba, misi ini tidak berubah hingga terbitnya Peraturan Pemerintah Nomor 103 tahun 2000 yang dijadikan sebagai landasan kegiatan usaha Perum Pegadaian sampai sekarang. ${ }^{2}$

Pembiayaan merupakan tugas pokok lembaga keuangan, termasuk lembaga keuangan syariah yang berupa pemberian dana kepada pihak-pihak yang membutuhkan. Pembiayaan sendiri terdiri dari beberapa jenis dan model. Seluruhnya menjadi pilihan bagi masyarakat ataupun pihak yang membutuhkan dalam menentukan model pembiayaan yang akan digunakan. Sebagai hal yang baru, tentunya model pembiayaan yang disertai rahn masih belum memiliki payung hukum secara syar'i. Untuk menjawab permasalahan tersebut, Majelis Ulama Indonesia, dalam hal ini Dewan Syariah Nasional mengeluarkan fatwa perihal pembiayaan yang disertai rahn (al-tamwil al-mautsuq bil-rahn). ${ }^{3}$

Kehadiran fatwa perihal pembiayaan yang disertai rahn (altamwil al-mautsuq bil-rahn) ini, menjadikan solusi atas keresahan masyarakat umum, terkhusus pada nasabah dari Pegadaian Syariah. Dan menjadikan tolak ukur terhadap pengetahuan masyarakat pada pembiayaan yang disertai rahn (al-tamwil al-mautsuq bil-rahn) yang

\footnotetext{
${ }^{2}$ Kutipan ini diperoleh dari tulisan Ari Agung Nugraha seorang Manager Pegadaian Syariah Cabang Sei Panas- Batam. Tulisannya mengangkat judul tentang " Gambaran Umum Kegiatan Usaha Pegadaian Syariah ”, (Batam: Pegadaian Syariah Cabang Sei Panas- Batam, 2010). http://ulgs.tripod.com./aboutme.htm. (20 September 2019)

${ }^{3}$ Habib Wakidatul Ihtiar, Analisis Fatwa Dewan Syariah Nasional Nomor: 92/DSN-MUI/IV/2014 tentang Pembiayaan yang Disertai Rahn, vol. 03, no.1 (Tulungagung: An-nisbah, 2016). 25. http://ejournal.iaintulungagung.ac.id/index.php/nisbah/article/view/274/210. (01Agustus 2019).
} 
diterapkan oleh Pegadaian Syariah dengan didasarkan pada fatwa yang berlaku. Karena sebagai bukti kurangnya pengetahuan masyarakat, terutama nasabah Pegadaian Syariah khususnya Pegadaian Syariah Cabang Palu Plasa Kota Palu adalah masyarakat yang masih mengenal dengan biaya ujrah, ketika mereka ingin menggadai barang jaminan yang dijaminkan masih diterapkan di Pegadaian Syariah. ${ }^{4}$ Namun, bila sesuai dengan Fatwa Dewan Syariah Nasional nomor 92 tahun 2014, Pegadaian Syariah sudah tidak menerapkan ujrah (biaya sewa) dalam penetapan biaya tapi beralih menjadi biaya mu'nah (biaya pemeliharaan) terhadap barang jaminan. ${ }^{5}$

Bukti ini menjadikan dasar untuk ditetapkannya fatwa tersebut, pastilah berawal dari sebuah latar belakang dan alasanalasan penting. Selain itu, proses ijtihad yang dilakukan oleh DSNMUI dalam menetapkan fatwa diatas juga menarik untuk dikaji dalam lingkup pengimplementasian terhadap kalangan siapa pun, terutama masyarakat. Dengan demikian, untuk memecahkan masalah tersebut tulisan ini berusaha menjawab pertanyaan berikut ini:

Bagaimana implementasi Fatwa Dewan Syariah Nasional Majelis Ulama Indonesia (DSN-MUI) Nomor: 92/DSNMUI/IV/2014 terhadap pembiayaan pada produk rahn di Pegadaian Syariah Cabang Palu Plasa?

Untuk itu, tulisan ini bertujuan untuk menjelaskan bagaimana implementasi Fatwa Dewan Syariah Nasional Majelis Ulama Indonesia (DSN-MUI) Nomor: 92/DSN-MUI/IV/2014 terhadap pembiayaan pada produk rahn di Pegadaian Syariah Cabang Palu Plasa.

\section{Metode Penelitian}

Penelitian ini merupakan kategori penelitian lapangan (field research), maksud dan tujuan penulis mengambil penelitian

\footnotetext{
${ }^{4}$ Nur Muzdalifah, Nasabah Produk Rahn di Pegadaian Syariah Cabang Palu Plasa, wawancara, Palu. (05 Agustus 2019).

5 Rezki Octavian, Karyawan Pegadaian Syariah Cabang Palu Plasa, wawancara, Palu. (01 Agustus 2019).
} 
lapangan (field research) ini adalah untuk mempelajari secara intensif tentang latar belakang keadaan sekarang, dan interaksi lingkungan suatu unit sosial, baik secara individu, kelompok, lembaga, atau masyarakat. ${ }^{6}$ Penelitian ini di desain dengan menggunakan jenis penelitian deskriptif, dan menggunakan pendekatan kualitatif. Yang selanjutnya Neuman mengungkapkan bahwa data kualitatif adalah dalam bentuk teks, kata-kata tertulis, frase-frase, atau simbol-simbol yang mendeskripsikan atau mempresentasikan orang-orang, tindakan-tindakan, dan peristiwaperistiwa dalam kehidupan sosial. ${ }^{7}$ Dalam rangka mempermudah peneliti dalam mengumpulkan data-data, ada beberapa teknik pengumpulan yang digunakan untuk mengumpulkan data yang dibutuhkan untuk menjawab rumusan masalah penelitian. Adapun beberapa teknik penelitian yang digunakan dalam mengumpulkan data, yakni observasi, wawancara, dan dokumentasi. Dengan teknik pengumpulan yang disebutkan, sehingga dapat mempermudah dalam mengakses bahan-bahan atau sumber-sumber yang dibutuhkan.

\section{Hasil dan Pembahasan}

\section{Pembiayaan Syariah}

Kegiatan pembiayaan syariah meliputi sejumlah pembiayaan yang terdiri dari sejumlah akad sebagai berikut:

a. Pembiayaan jual beli, yaitu pembiayaan dalam bentuk penyediaan barang melalui transaksi jual beli sesuai dengan perjanjian pembiayaan syariah yang disepakati oleh para pihak. Akad yang digunakan dalam pembiyaan jual beli antara lain murabahah, salam, dan Istishna'.

b. Pembiayaan investasi, yaitu pembiayaan dalam bentuk penyediaan modal dengan jangka waktu tertentu untuk kegiatan

6 Sumadi Suryabrata, Metodologi Penelitian, Cet. 23, (Jakarta: PT Rajagrafindo Persada, 2012), 80.

${ }^{7}$ Lihat pendapat dari Bogdan dan Bikken tentang pengertian data, dan juga pengertian data kualitatif dari pendapat Neuman pada buku yang dikarang oleh Muhamad, Metodologi Penelitian Ekonomi Islam: Pendekatan Kuantitatif (Dilengkapi dengan Contoh-contoh Aplikasi: Proposal Penelitian dan Laporannya), (Jakarta: PT Rajagrafindo Persada, 2008), 108. 
usaha produktif dengan pembagian keuntungan sesuai dengan perjanjian pembiayaan syariah yang disepakati oleh para pihak. Akad yang digunakan dalam pembiayaan investasi antara lain mudharabah, musyarakah, mudharabah musytarakah, dan musyarakah mutanaqishah.

c. Pembiayaan jasa, pemberian/penyediaan jasa baik dalam bentuk pemberian manfaat atas suatu barang, pemberian pinjaman (dana talangan) dan/atau pemberian pelayanan dengan dan/atau tanpa pembayaran imbal jasa (ujrah) sesuai dengan perjanjian pembiayaan syariah yang disepakati oleh para pihak. Akad yang digunakan dalam pembiayaan jasa antara lain ijarah, ijarah muntahiyah bittamlik, hawalah atau hawalah bil ujrah, wakalah atau wakalah bil ujrah, kafalah atau kafalah bil ujrah, ju'alan. ${ }^{8}$

Secara hukum, fatwa DSN-MUI menyatakan semua bentuk pembiayaan/penyaluran dana Lembaga Keuangan Syariah (LKS) boleh dijamin dengan agunan (rahn) sesuai ketentuan dalam fatwa ini. $^{9}$

Selain menawarkan pembiayaan yang disertai rahn sesuai fatwa DSN-MUI Nomor: 92/DSN-MUI/IV/2014 pada Pegadaian Syariah. Maka Pegadaian Syariah juga mengembangkan lini pembiayaan berbasis syariah dengan sejumlah produk dalam prakteknya, yakni pembiayaan:

a. Rahn: Pembiayaan rahn dari Pegadaian Syariah adalah solusi tepat kebutuhan dan cepat yang sesuai syariah. Prosesnya cepat hanya dalam waktu 15 menit dana cair dan aman penyimpanannya. Jaminan berupa barang perhiasan, elektronik, atau kendaraan bermotor.

b. Arrum: Pembiayaan arrum pada Pegadaian Syariah memudahkan para pengusaha kecil untuk mendapatkan modal usaha dengan jaminan BPKB dan emas. Kendaraan tetap pada pemiliknya

${ }^{8}$ Lihat bagian prinsip dan kegiatan usaha pembiayaan syariah pada buku yang dikarang oleh Andri Soemitra, Bank dan Lembaga Keuangan Syariah, Cet. 7, (Jakarta: Kencana, 2017), 351-352.

${ }^{9}$ Lihat ketentuan umum pada Fatwa DSN-MUI Nomor: 92/DSNMUI/IV/2014 tetang pembiayaan yang disertai rahn, Situs Resmi DSN-MUI, 4. https://dsnmui.or.id/kategori/fatwa/page/4/ (15 Oktober 2019) 
sehingga dapat digunakan untuk mendukung usaha sehari-hari. Maksimalkan daya guna kendaraan.

c. Amanah: Pembiayaan amanah dari Pegadaian Syariah adalah pembiayaan berprinsip syariah kepada pegawai negeri sipil dan karyawan swasta untuk memiliki motor atau mobil dengan cara angsuran. ${ }^{10}$

\section{Implementasi Fatwa dan Dewan Syariah Nasional}

a. Implementasi Fatwa

Fatwa dalam pengertian Ensiklopedi Islam adalah pendapat atau keputusan mengenai ajaran Islam yang disampaikan oleh lembaga atau perorangan yang diakui otoritasnya yakni mufti. ${ }^{11}$ Fatwa bisa untuk memberikan solusi atas pertanyaan yang diajukan. Selain fatwa dapat memberikan solusi atas pertanyaan yang diajukan, dapat juga berfungsi sebagai respon atas perkembangan permasalahan yang bersifat kekinian atau kontemporer karena masyarakat membutuhkannya sesuai dengan perkembangan dan perubahan zaman. Hubungannya antara pembiayaan dengan fatwa adalah, pembiayaan merupakan tugas pokok lembaga keuangan, termasuk lembaga keuangan syariah yang berupa pemberian dana kepada pihak-pihak yang membutuhkan. Pembiayaan sendiri terdiri dari beberapa jenis dan model. Seluruhnya menjadi pilihan bagi masyarakat ataupun pihak yang membutuhkan dalam menentukan model pembiayaan yang akan digunakan. Fenomena yang muncul di masyarakat akhir-akhir ini ialah terjadinya akad pembiayaan yang didalamnya disertakan rahn (gadai). Sebagai hal yang baru, tentunya model pembiayaan yang disertai rahn masih belum memiliki payung hukum secara syar'i. Untuk menjawab permasalahan tersebut, Majelis Ulama Indonesia, dalam hal ini Dewan Syariah Nasional mengeluarkan fatwa perihal pembiayaan yang disertai rahn (altamwil al-mautsūq bil-rahn). Sebagai salah satu bukti dari

${ }^{10}$ Lihat bagian prinsip dan kegiatan usaha pembiayaan syariah pada buku yang dikarang oleh Andri Soemitra, Bank dan Lembaga Keuangan Syariah, .412414

${ }^{11}$ Lihat pengertian kata fatwa pada buku yang dikarang oleh Huston Smith, Ensiklopedi Islam (Ringkas), cet. 2, (Jakarta: PT Rajagrafindo Persada, 2002), 98. 
implementasi fatwa ini harus diterapkan pada lembaga keuangan syariah adalah kecocokannya antara pembiayaan yang diterapkan oleh lembaga keuangan syariah.

Fatwa memberikan kebolehan (halal) pada beberapa jenis akad pembiayaan untuk disertai rahn. Akad tersebut terdiri yakni: akad utang-piutang (al-dain), jual beli (al-ba"i) yang tidak tunai, sewa-menyewa (ijarah) yang pembayaran ujrahnya tidak tunai, musyarakah (perkongsian), mudharabah, dan akad amanah (untuk menghindari penyelewengan perilaku). Jika implementasi fatwa mampu diterapkan pada lembaga keuangan syariah, maka Fatwa merupakan kaidah dan asas yang dianggap penting dan diperlukan dalam rangka memperlancar aktivitas ekonomi syariah, apakah bentuknya telah ditransformasi ke dalam peraturan perundangundangan ataupun belum ditransformasikan. ${ }^{12}$

b. Dewan Syariah Nasional

1) Sejarah dan Pengertian Dewan Syariah Nasional

Pada saat ini, Lembaga Keuangan Syariah, Lembaga Bisnis Syariah dan Lembaga Perekonomian Syariah di Indonesia mengalami kemajuan yang pesat. Untuk mendukung perkembangan tersebut diperlukan dukungan para pihak terkait guna memberikan pembinaan, pengawasan, dan arahan yang memungkinkan perkembangan lembaga-lembaga tersebut berjalan dengan sehat dan berkelanjutan.

Salah satu bentuk dukungan yang diberikan Majelis Ulama Indonesia adalah dibentuknya Dewan Syariah Nasional-Majelis Ulama Indonesia (DSN-MUI) pada tanggal 10 Februari 1999. DSN-MUI dibentuk untuk melaksanakan tugas MUI dalam menetapkan fatwa dan mengawasi penerannya guna menumbuhkembangkan usaha bidang keuangan, bisnis, dan ekonomi syariah di Indonesia.

${ }^{12}$ Andi Fariani, Urgensi Fatwa MUI dalam Pembangunan Sistem Hukum Ekonomi Islam di Indonesia, vol. 12. no. 1 (Jakarta: al-Ihkam, 2017), 101. http://ejournal. stainpamekasan. ac.id/index.php/alihkam/article/view/1191/951. (16 Oktober 2019). 
Sebagai lembaga yang otoritatif dalam bidang fatwa terkait keuangan, bisnis, dan perekonomian syariah pada umumnya, DSN-MUI perlu melakukan penataan organisasi yang kuat dengan didasari pada prinsip-prinsip transparansi, akuntabilitas, pertanggungjawaban, kemandirian, kesetaraan, dan profesionalisme. ${ }^{13}$

Adapun pengertian dari Dewan Syariah Nasional-Majelis Ulama Indonesia, diatur pada bagian Anggaran Dasar Dewan Syariah Nasional-Majelis Ulama Indonesia dalam Bab I Ketentuan Umum Pasal 1 ayat 1, yang menyebutkan:

Pasal 1 ayat 1 :

Dewan Syariah Nasional-Majelis Ulama Indonesia, yang selanjutnya disingkat DSN-MUI, adalah lembaga yang melaksanakan tugas MUI dalam menetapkan fatwa dan mengawasi penerapannya dalam rangka menumbuhkembangkan usaha bidang keuangan, bisnis, dan ekonomi syariah di Indonesia. ${ }^{14}$

2) Tugas dan Wewenang Dewan Syariah Nasional

Tugas Dewan Syariah Nasional-Majelis Ulama Indonesia diatur pada Bab III Tugas dan Wewenang DSN-MUI pada Pasal 4 ayat $1-12$, yang menyebutkan:

Pasal 4

DSN-MUI mempunyai tugas:

a) Menetapkan fatwa atas system, kegiatan, produk, jasa LKS, dan LPS lainnya.

b) Mengawasi penerapan fatwa melalui DPS di LKS, dan LPS lainnya.

\footnotetext{
${ }^{13}$ Lihat pada Peraturan Organisasi Majelis Ulama Indonesia Nomor: Kep407/MUI/IV/2016 tentang Anggaran Dasar dan Anggaran Rumah Tangga Dewan Syariah Nasional-Majelis Ulama Indonesia pada bagian Mukadimah. https://dsnmui.or.id/kami/ad-art-dsn-mui/. (15 Oktober 2019)

${ }^{14}$ Lihat pada Peraturan Organisasi Majelis Ulama Indonesia Nomor: Kep407/MUI/IV/2016 tentang Anggaran Dasar dan Anggaran Rumah Tangga Dewan Syariah Nasional-Majelis Ulama Indonesia pada bagian Ketentuan Umum. https://dsnmui.or.id/kami/ad-art-dsn-muil. (15 Oktober 2019)
} 
c) Membuat pedoman implementasi fatwa untuk lebih menjabarkan fatwa tertentu agar tidak menimbulkan multi penafsiran pada saat di implementasikan di LKS dan LPS lainnya.

d) Mengeluarkan surat edaran (ta'limat) kepada LKS dan LPS lainnya.

e) Memberikan rekomendasi calon anggota dan/atau mencabut rekomendasi anggota DPS pada LKS dan LPS lainnya.

f) Memberikan rekomendasi calon ASPM dan/atau mencabu rekomendasi ASPM.

g) Menerbitkan pernyataan kesesuaian syariah atau keselarasan syariah bagi produk dan ketentuan yang diterbitkan oleh otoritas terkait.

h) Menerbitkan pernyataan kesesuaian syariah atas system, kegiatan, produk, jasa di LKS, dan LPS lainnya.

i) Menerbitkan sertifikat kesesuaian syariah bagi LBS dan LPS lainnya yang memerlukan.

j) Menyelenggarakan program sertifikasi keahlian syariah bagi LKS dan LPS lainnya.

k) Melakukan sosialisasi dan edukasi dalam rangka meningkatkan literasi keuangan, bisnis, dan ekonomi syariah.

1) Menumbuh kembangkan penerapan nilai-nilai syariah dalam kegiatan perekonomian pada umumnya dan keuangan pada khususnya. ${ }^{15}$

Wewenang dari Dewan Syariah Nasional-Majelis Ulama Indonesia juga diatur dalam Bab III Tugas dan Wewenang DSNMUI pada Pasal 5 ayat 1-6, yang menyebutkan:

\section{Pasal 5}

DSN-MUI mempunyai wewenang, yaitu:

a) Mengeluarkan fatwa yang mengikat DPS di masing-masing Lembaga Keuangan Syariah (LKS) dan menjadi dasar tindakan hukum terkait.

${ }^{15}$ Lihat pada Peraturan Organisasi Majelis Ulama Indonesia Nomor: Kep407/MUI/IV/2016 tentang Anggaran Dasar dan Anggaran Rumah Tangga Dewan Syariah Nasional-Majelis Ulama Indonesia pada bagian Tugas dan Wewenang DSN-MUI. https://dsnmui.or.id/kami/ad-art-dsn-mui/. (15 Oktober 2019) 
b) Mengeluarkan fatwa yang menjadi landasan bagi ketentuan/peraturan yang dikeluarkan oleh instansi yang berwenang, seperti departemen keuangan dan Bank Indonesia.

c) Memberikan rekomendasi dan mencabut rekomendasi namanama yang akan duduk sebagai DPS pada suatu LKS.

d) Mengundang para ahli untuk menjelaskan suatu masalah yang diperlukan dalam pembahasan ekonomi syariah, termasuk otoritas monoter/lembaga keuangan dalam Negeri maupun luar Negeri.

e) Memberikan peringatan kepada LKS untuk menghentikan penyimpangan dari fatwa yang telah dikeluarkan oleh DSN.

f) Mengusulkan kepada instansi yang berwenang untuk mengambil tindakan apabila peringatan tidak diindahkan. ${ }^{16}$

\section{Latar Belakang DSN-MUI Menetapkan Fatwa No. 92/DSN- MUI/IV/2014}

Dewan Syariah Nasional Majelis Ulama Indonesia (DSNMUI) dalam menetapkan fatwa No. 92 Tahun 2014 ini dilatar belakangi oleh beberapa hal, yaitu:

Pertama, fatwa-fatwa DSN-MUI tentang rahn dipandang belum mengakomodasi pengembangan usaha berbasis rahn. Kedua, lembaga Keuangan Syariah memerlukan fatwa terkait pengembangan usaha berbasis rahn. ${ }^{17}$

\section{Sejarah Pegadaian Syariah Cabang Palu Plasa}

Konsep operasi syariah mengacu pada sistem administrasi model yaitu azas rasionalitas, efisiensi dan efektifitas yang diselaraskan dengan nilai Islam. Fungsi operasi Pegadaian Syariah itu sendiri dijalankan oleh kantor-kantor Cabang Pegadaian Syariah /ULGS sebagai satu unit organisasi di bawah binaan Divisi Usaha

\footnotetext{
${ }^{16}$ Ibid.

${ }^{17}$ Habib Wakidatul Ihtiar, Analisis Fatwa Dewan Syariah Nasional Nomor: 92/DSN-MUI/IV/2014 tentang Pembiayaan yang Disertai Rahn, vol. 03, no.1 (Tulungagung: An-nisbah, 2016). 30-31. $\underline{\text { http://ejournal.iain- }}$ tulungagung.ac.id/index.php/nisbah/article/view/274/210. (15 Oktober 2019)
} 
lain. ULGS ini merupakan unit bisnis mandiri yang secara struktur terpisah pengelolaannya dari usaha gadai konvensional.

Pegadaian Syariah pertama kali berdiri di Jakarta dengan nama Unit layanan Gadai Syariah (ULGS) Cabang Dewi Sartika di bulan Januari tahun 2003. Menyusul kemudian pendirian ULGS di Surabaya, Makassar, Semarang, Surakarta, dan Yogyakarta di tahun yang sama hingga September 2003. Dan 4 Kantor Cabang Pegadaian di Aceh dikonversi menjadi Pegadaian Syariah. ${ }^{18}$

Banyak pihak berpendapat bahwa operasionalisasi Pegadaian pra Fatwa Majelis Ulama Indonesia tanggal 16 Desember 2003 tentang bunga bank, telah sesuai dengan konsep syariah meskipun harus diakui belakang bahwa terdapat beberapa aspek yang menepis anggapan itu. Prinsip syariah adalah aturan perjanjian berdasarkan hukum Islam antara lembaga keuangan dan pihak lain untuk penyimpanan dana dan/atau pembiyayaan kegiatan usaha, atau kegiatan lainnya yang sesuai dengan syariah. Seiring berjalannya waktu, pegadaian syariah masuk di Kota Manado dan berhasil menduduki peringkat terbaik dan omset tertinggi di kantor wilayah Manado perkembangan pegadaian syariah mengalami peningkatan, hal ini ditandai dengan banyaknya membuka cabang-cabang di seluruh wilayah Indonesia salah satunya di Sulawesi Tengah, tepatnya di Kota Palu, sehingga pada tanggal 10 Maret 2004 dibuka kantor Cabang Pegadaian Syariah Palu Plasa di Kota Palu. ${ }^{19}$

Hadirnya Pegadaian Syariah Cabang Palu Plasa di tengah masyarakat Kota Palu yang telah dulu mengenal Pegadaian Konvensional bukan hal yang mudah. Memerlukan usaha yang sangat giat untuk memperkenalkan Pegadaian yang berbasis Islam untuk merebut hati masyarakat. Sehingga pimpinan dari para staf melakukan berbagai langkah pemasaran dalam memperkenalkan Pegadaian Syariah untuk merebut hati masyarakat melalui pemasaran produk dan peningkatan kualitas pelayanan. CPS Palu Plasa dituntut untuk mempunyai strategi pertahanan pertahanan untuk merebut dan nempertahankan nasabah melalui kualitas produk

\footnotetext{
${ }^{18}$ Sejarah Pegadaian Syariah Cabang Palu Plasa, dokumentasi, Kantor Pegadaian Syariah Cabang Palu Plasa, Palu. (06 Januari 2020). (06 Januari 2020)

${ }^{19}$ Ibid. (06 Januari 2020)
} 
dan jasa, yaitu waktu penyerahan lebih cepat, pelayanan yang lebih baik dibandingkan pesaingnya, dan empati yang tinggi kepada nasabah agar ikut dalam persaingan. Alasan pegadaian membuka pegadaian syariah adalah pertama upaya untuk mempertahankan posisi pasar dengan jalan memberikan respon atas tuntutan masyarakat luas yang membutuhkan transaksi jasa keuangan yang didasarkan pada prinsip keadilan dan bebas dari unsur riba dan kedua adalah menggapai ridha Allah sesuai dengan dengan al-Quran dan hadis.

\section{Produk dan Jenis Akad pada Pembiayaan Produk rahn}

a. Produk rahn

Produk ini merupakan produk andalan pada Pegadaian Syariah yang merupakan pinjaman mudah dan praktis untuk memenuhi kebutuhan dana bagi masyarakat dengan menggunakan sistem syariah. ${ }^{20}$

b. Jenis Akad pada Pembiayaan pada Produk rahn

Produk ar-rahn menggunakan jenis akad rahn. Dengan ketentuan produk ar-rahn ini, nasabah memberikan atau menyerahkan barang jaminan kepada pihak pegadaian, dengan cara menyerahkan agunan berupa emas batangan, emas perhiasan, berlian, elektronik, dan kendaraan bermotor. ${ }^{21}$ Sesuai ketentuan umum pada Fatwa Dewan Syariah Nasional Nomor 92/DSNMUI/IV/2014 menyebutkan bahwa:

Akad Rahn adalah sebagaimana dalam fatwa DSN-MUI Nomor: 25/DSN-MUI/III/2002 tentang Rahn; fatwa DSN-MUI Nomor: 26/DSN-MUI/III/2002 tentang Rahn Emas; dan fatwa DSN-MUI Nomor: 68/DSN-MUI/III/2008 tentang Rahn Tasjily. ${ }^{22}$

\footnotetext{
${ }^{20}$ Lihat tentang produk ar-rahn pada situs resmi Pegadaian Syariah. https://pegadaiansyariah .co.id/ rahn. (24 Januari 2020)

${ }^{21}$ Jenis akad rahn, dokumentasi, Pegadaian Syariah Cabang Palu Plasa, Palu. (16 Januari 2020)

${ }^{22}$ Lihat ketentuan umum pada Fatwa DSN-MUI Nomor: 92/DSNMUI/IV/2014 tentang Pembiayaan yang Disertai rahn, Situs Resmi DSN-MUI, 4. https://dsnmui.or.id/kategori/fatwa/page/4/ (16 Januari 2020)
} 
Dijelaskan juga pada ketentuan umum pada Fatwa Dewan Syariah Nasional Nomor: 25/DSN-MUI/III/2002 tentang Rahn; menyebutkan:

Murtahin (penerima gadai) mempunyai hak untuk menahan marhun (barang) sampai semua utang rāhin (yang menyerahkan barang) dilunasi. ${ }^{23}$

\section{Barang Jaminan yang Diterima Pegadaian Syariah Cabang Palu Plasa}

a. Handphone

b. Emas

c. Barang eletronik seperti laptop, kamera dan tv

d. Tupperware

e. Motor atau Mobil.

7. Jumlah Nasabah Pegadaian Syariah Cabang Palu Plasa

Nasabah merupakan salah satu rukun dari bermualamah di Pegadaian Syariah. Dalam istilah muamalah, nasabah disebut sebagai rāhin. Adapun yang menjadikan syarat sebagai nasabah (rāhin) adalah cakap bertindak hukum, dan juga layak untuk melakukan transaksi kepemilikan. ${ }^{24} \mathrm{Hal}$ ini, juga disampaikan oleh salah satu pegawai dari Pegadaian Syariah Cabang Palu Plasa. Pihak pegadaian syariah akan melihat nasabah (rähin) yang berkeinginan untuk memilih produk-produk yang sudah ada diterapkan di Pegadaian Syariah Cabang Palu Plasa. Adapun karyawan tersebut menyampaikan bahwa:

Kalau di syariah, nama muamalahnya itu rāhin. Rāhin adalah nasabah pegadaian yang mempunyai barang jaminan sesuai ketentuan yang ada di pegadaian syariah. Rāhin adalah nasabah yang mempunyai barang jaminan seperti emas, barang elektronik,

\footnotetext{
${ }^{23}$ Lihat ketentuan umum angka 1 pada Fatwa DSN-MUI Nomor: 25/DSNMUI/III/2002 tentang rahn, Situs Resmi DSN-MUI, 3. https://dsnmui.or.id/kategori/fatwa/page/4/ (16 Januari 2020)

${ }^{24}$ Muhammad Nur Rianto Al-Arif, Lembaga Keuangan Syariah (Suatu Kajian Teoretis Praktis), Cet. 2, (Bandung: CV Pustaka Setia, 2017), 284.
} 
kendaraan atau bukti kepemilikan (BPKB dan sertifikat), dan tupperware. ${ }^{25}$

Berikut ini disajikan tabel jumlah nasabah sesuai produk yang dipilih oleh nasabah dalam bemuamalah di Pegadaian Syariah Cabang Palu Plasa:

Tabel 4.1

Jumlah nasabah

Per-Bulan November 2019-Desember $2019^{26}$

\begin{tabular}{|c|l|r|r|}
\hline \multirow{2}{*}{ No } & \multirow{2}{*}{ Produk } & \multicolumn{2}{|c|}{ Realisasi } \\
\cline { 3 - 4 } & & Nov-19 & \multicolumn{1}{c|}{ Des-19 } \\
\hline 1 & 2 & 3 & \multicolumn{1}{|c|}{4} \\
\hline 1 & Amanah & 144 & 142 \\
\hline 2 & Arrum & 322 & 309 \\
\hline 3 & Rahn & 3.792 & 3.748 \\
\hline \multicolumn{2}{|c|}{ Total } & 4.258 & 4.199 \\
\hline
\end{tabular}

Tabel di atas, dapat dipahami bahwa jumlah nasabah perBulan November 2019 sampai perakhir Bulan Desember 2019, cukup ada perubahan dari jumlah nasabah yang memilih produkproduk yang ada di Pegadaian Syariah Cabang Palu Plasa. Perubahan dapat terlihat dari jumlah nasabah yang memilih produk rahn. Terlihat ada penurunan jumlah nasabah dalam memilih ketiga dari produk tersebut. Produk rahn terdapat penurunan jumlah nasabah sebanyak 44 nasabah, dari jumlah nasabah pada akhir Bulan November 2019 sebanyak 3.792 menjadi 3.748 pada akhir Bulan Desember 2019. Alasan kenapa ada perubahan jumlah nasabah perakhir Bulan November 2019 sampai perakhir Bulan Desember 2019 yang semakin menurun, penulis menyempatkan waktu untuk

\footnotetext{
${ }^{25}$ Reni .A. Hipan, Pegawai Pegadaian Syariah Cabang Palu Plasa, wawancara, Pegadaian Syariah Cabang Palu Plasa, Palu (02 Januari 2020)

${ }^{26}$ Reni .A. Hipan, Pegawai Pegadaian Syariah Cabang Palu Plasa, wawancara, Pegadaian Syariah Cabang Palu Plasa, Palu. (02 Januari 2020)
} 
menanyakan alasannya pada pihak Pegadaian Syariah, melalui wawancara. Pihak Pegadaian Syariah Cabang Palu Plasa, menyebutkan:

Bisa jadi, karna sudah menyelesaikan akad atau kreditnya sudah lunas. Di kita terhitung nasabah aktif, jika nasabahnya masih mempunyai kredit. ${ }^{27}$

\section{Prosedur Pembiayaan pada Produk Rahn}

Prosedur atau tahapan dalam pembiayaan produk rahn dimulai dengan nasabah datang ke kantor Pegadaian Syariah Cabang Palu Plasa dengan membawa syarat dan memenuhi beberapa ketentuan yang berlaku dalam pembiayaan produk rahn. ${ }^{28}$ Adapun syarat yang harus dipenuhi dalam pembiayaan produk rahn adalah sebagai berikut:

1) Membawa fotocopy KTP atau Identitas lainnya.

2) Mengisi formulir permintaan rahn.

3) Menyerahkan barang jaminan. ${ }^{29}$

Setelah nasabah memenuhi syarat dan ketentuan yang sudah disepakati dengan pihak pegadaian, prosedur selanjutnya yaitu nasabah menerima dan setuju terhadap uraian marhun (barang jaminan), penetapan besarnya taksiran marhun (barang jaminan), marhuh bih (uang pinajaman), tarif mu'nah (biaya) pemeliharaan, mu'nah (biaya) akad, biaya pemeliharaan marhun (barang jaminan) dalam proses lelang (jika ada), biaya proses lelang (jika ada), bea lelang sebagaimana dimaksud pada Surat Bukti Rahn (SBR) atau nota transaksi (struk) sebagai tanda bukti yang sah penerimaan marhun bih (uang pinjaman) dan uang kelebihan lelang (jika ada). Kemudian prosedur dari barang yang diserahkan sebagai marhun (barang jaminan) adalah milik rāhin (nasabah) dan/atau kepemilikan

\footnotetext{
${ }^{27}$ Reni .A. Hipan, Karyawan Pegadaian Syariah Cabang Palu Plasa, wawancara, Pegadaian Syariah Cabang Palu Plasa, Palu (06 Januari 2020)

${ }^{28}$ Prosedur pembiayaan produk rahn, dokumentasi, Pegadaian Syariah Cabang Palu Plasa, Palu. (30 Januari 2020)

${ }^{29}$ Reni .A. Hipan, Karyawan Pegadaian Syariah Cabang Palu Plasa, wawancara, Pegadaian Syariah Cabang Palu Plasa, Palu. (02 Januari 2020)
} 
sebagaimana pasal 1977 KUH-Perdata dan/atau milik pemberi kuasa

\begin{tabular}{|c|c|c|}
\hline Golongan & Marhun bih (utang) & $\begin{array}{c}\text { Tarif per 10 hari } \\
\text { (n\% x taksiran } \\
\text { marhun })\end{array}$ \\
\hline A & 50.000 s.d 500.000 & $0,47 \%$ \\
\hline B1 & 510.000 s.d 5.000 .000 & $0,73 \%$ \\
\hline C1 & 5.050 .000 s.d 20.000 .000 & $0,73 \%$ \\
\hline D & 20.050 .000 s.d ke atas & $0,64 \%$ \\
\hline
\end{tabular}

atas marhun (barang jaminan) yang dikuasakan kepada nasabah dan menjamin bukan berasal dari hasil kejahatan, tidak dalam objek sengketa dan/atau sita jaminan. Setelah itu, rāhin (nasabah) menyatakan telah berutang kepada murtahin (pegadaian) dan berkewajiban untuk membayar marhun bih (uang pinjaman) dan mu'nah (biaya pemeliharaan) pada saat pelunasan, atau membayar cicilan marhun bih (uang pinjaman) jika ada. Dan mu'nah (biaya pemeliharaan) akad pada saat perpanjangan. ${ }^{30}$

Tabel

Tarif mu'nah per 10 hari pada produk pembiayaan rahn.

Marhun (barang jaminan) yang telah dilunasi dan belum diambil oleh nasabah, terhitung sejak tanggal pelunasan sampai dengan sepuluh hari, tidak dikenakan jasa penitipan. Bila melebihi sepuluh hari dari tanggal pelunasan marhun (barang jaminan) tetap belum diambil, maka nasabah sepakat dikenakan jasa penitipan. Besaran jasa penitipan sesuai ketentuan yang berlaku di pegadaian atau sebesar yang tercantum di nota transaksi (struk). Jika marhun (barang jaminan) mengalami kerusakan atau hilang yang tidak

\footnotetext{
${ }^{30}$ Prosedur pembiayaan produk rahn, dokumentasi, Pegadaian Syariah Cabang Palu Plasa, Palu.. (30 Januari 2020)
} 
disebabkan oleh suatu bencana alam, maka murtahin (pegadaian) akan memberikan ganti kerugian setelah diperhitungkan dengan marhun bih (uang pinjaman) dan mu'nah (biaya) pemeliharaan sesuai ketentuan penggantian yang berlaku di murtahin (pegadaian). ${ }^{31}$

Marhun bih (uang pinjaman) sampai dengan tanggal jatuh tempo tidak dilakuakan pelunasan dan/atau perpanjangan akad, maka Pegadaian melakukan penjualan marhun (barang jaminan) melalui lelang. Jika proses pelaksanaan lelang sudah terjadi dan mendapatkan hasil penjualan lelang marhun (barang jaminan), maka hasil penjualan tersebut setelah dikurangi marhun bih (uang pinjaman), mu'nah lelang (jika ada), dan bea lelang yang merupakan kelebihan yang menjadi hak rahin (nasabah). Jangka waktu pengambilan uang kelebihan selama satu tahun sejak tanggal pemberitahuan hasil lelang kepada nasabah. Dan jika lewat waktu dari jangka waktu pengambilan uang kelebihan lelang, nasabah menyatakan setuju untuk menyalurkan uang kelebihan lelang tersebut sebagai sedekah yang pelaksanaannya diserahkan kepada pegadaian. Jika hasil penjualan lelang marhun (barang jaminan) tidak mencukupi untuk melunasi kewajiban nasabah berupa dikurangi marhun bih (uang pinjaman), mu'nah lelang (jika ada), biaya proses lelang (jika ada), dan bea lelang, maka nasabah wajib membayar kekurangan tersebut. ${ }^{32}$

Nasabah dapat melakukan ulang rahn, atau minta tambah marhun bih (uang pinjaman) selama nilai taksiran masih memenuhi syarat dengan memperhitungkan biaya mu'nah(biaya) pemeliharaan dan mu'nah (biaya) akad yang masih harus dibayar. Jika terjadi penurunan nilai taksiran marhun (barang jaminan) pada saat ulang rahn, maka nasabah wajib melakukan pelunasan atau mengangsur (mencicil) marhun bih (uang pinjaman) atau menambah marhun (barang jaminan) agar sesuai dengan taksiran baru. Caranya nasabah untuk melakukan ulang rahn adalah nasabah dapat datang sendiri untuk melakukan ulang rahn atau minta tambah marhun bih (uang pinjaman) atau mengangsur marhun bih (uang pinjaman) atau

\footnotetext{
${ }^{31}$ Ibid. (30 Januari 2020)

${ }^{32}$ Ibid. (30 Januari 2020)
} 
pelunasan atau menerima marhun (barang jaminan), atau menerima uang kelebihan lelang, dan/atau dapat dengan memberikan kuasa kepada orang lain dengan mengisi dan membubuhkan tanda tangan kolom yang tersedia, dengan melampirkan fotokopi KTP nasabah dan penerima kuasa serta menunjukkan asli KTP penerima kuasa. Dalam hal nasabah atau kuasanya melakukan pengambilan marhun (barang jaminan) atau pengambilan uang kelebihan lelang, maka hanya dilayani di Kantor Cabang Syariah/Unit Syariah Pegadaian yang menerbitkan Surat Bukti Rahn. ${ }^{33}$

Apabila nasabah meninggal dunia dan terdapat hak dan kewajiban terhadap murtahin (pegadaian) ataupun sebaliknya, maka hak dan kewajiban dibebankan kepada ahli waris rāhin (nasabah) sesuai dengan ketentuan waris dalam hukum Republik Indonesia. Dan apabila dikemudian hari terjadi perselisihan, maka akan diselesaikan secara musyawarah untuk mufakat dan apabila terjadi kesepakatan akan diselesaikan melalui Pengadilan Agama setempat. $^{34}$

Berikut di bawah ini gamabr alur model bisnis produk rahn di Pegadaian Syariah: ${ }^{35}$

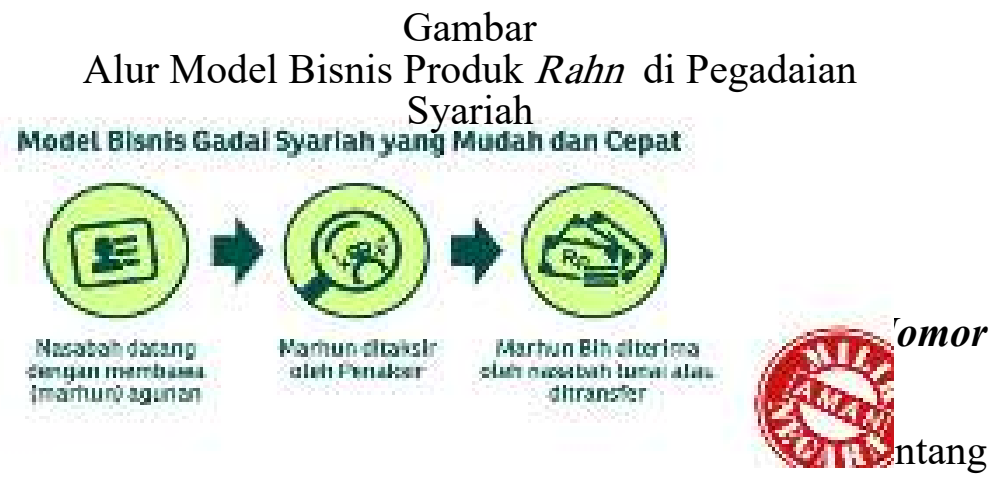

pembiayaan yang disertai rahn pada nomor ketiga angka satu bahwa

\footnotetext{
${ }^{33}$ Kuasa nasabah untuk melakukan pengambilan marhun (barang jaminan), dokumentasi, Pegadaian Syariah Cabang Palu Plasa, Palu. (30 Januari 2020)

${ }^{34}$ Ibid. (29 Januari 2020)

${ }^{35}$ Lihat gambar alur model bisnis produk rahn pada situs resmi Pegadaian Syariah, https://pegadaiansyariah.co.id/rahn. (01 Februari 2020)
} 
barang jaminan (marhun) harus berupa harta (mā) berharga baik benda bergerak maupun tidak bergerak yang boleh dan dapat diperjual-belikan, termasuk aset keuangan berupa sukuk, efek syariah atau surat berharga syariah. ${ }^{36}$ Maka implementasi ketentuan tersebut dalam praktik di Pegadaian Syariah sesuai dari hasil wawancara dengan salah satu karyawan Pegadaian Syariah Cabang Palu Plasa. Barang jaminan yang diterima Pegadaian Syariah Cabang Palu Plasa yakni hendphone, emas, kendaraan (motor ataupun mobil), elektronik lainnya sampai tuperware. ${ }^{37}$ Namun, sesuai hasil pantauan atau observasi, kebanyakan nasabah di Pegadaian Syariah menggadaikan barang jaminannya dalam berupa emas dibandingkan dengan barang lainnya yang bisa dijaminkan di pegadaian.

Fatwa Nomor 92/DSN-MUI/IV/2014 tentang pembiayaan yang disertai rahn pada nomor ketiga angka dua bahwa dalam hal barang jaminan (marhun) merupakan musya' (bagian dari kepemilikan bersama/part of undivided ownership), maka musya' yang digadaikan harus sesuai dengan porsi kepemilikannya. ${ }^{38}$ Implementasi fatwa dalam produk ini yakni barang yang diserahkan sebagai marhun (barang jaminan) adalah milik rahin (nasabah) dan/atau kepemilikan sebagaimana pasal 1977 KUH-Perdata dan/atau milik pemberi kuasa atas marhun (barang jaminan) yang dikuasakan kepada nasabah dan menjamin bukan

${ }^{36}$ Lihat ketentuan terkait barang jaminan (marhun) nomor ketiga angka satu pada Fatwa DSN-MUI Nomor: 92/DSN-MUI/IV/2014 tentang Pembiayaan yang Disertai Rahn, Situs Resmi DSN-MUI, 5. https://dsnmui.or.id/kategori/fatwa/page/5/ (13 Maret 2020)

${ }^{37}$ Reni .A. Hipan, Karyawan Pegadaian Syariah Cabang Palu Plasa, wawancara, Pegadaian Syariah Cabang Palu Plasa, Palu (02 Januari 2020)

${ }^{38}$ Lihat ketentuan terkait barang jaminan (marhun) nomor ketiga angka dua pada Fatwa DSN-MUI Nomor: 92/DSN-MUI/IV/2014 tentang Pembiayaan yang Disertai Rahn, Situs Resmi DSN-MUI, 5. https://dsnmui.or.id/kategori/fatwa/page/5/ (13 Maret 2020) 
berasal dari hasil kejahatan, tidak dalam objek sengketa dan/atau sita jaminan. ${ }^{39}$

Dewasa ini, pemahaman penulis adalah sekalipun redaksi pasal 1977 ayat (2) tidak mengisyaratkan pemegang untuk mendapatkan penggantian uang yang telah dibayarkan olehnya untuk mendapatkan benda itu, iktikadnya harus baik. Namun sudah sewajarnya, bahwa hal itu harus dipenuhi (iktikad aik harus ada), karena pada dasarnya orang yang iktikadnya buruk tidak mendapatkan perlindungan hukum.

Ketentuan Fatwa Nomor 92/DSN-MUI/IV/2014 tentang pembiayaan yang disertai rahn pada nomor ketiga angka tiga yang menyebutkan bahwa barang jaminan (marhun) boleh diasuransikan sesuai peraturan perundang-undangan yang berlaku dan/atau kesepakatan. ${ }^{40}$ Dan adapun penerapan ketentuan fatwa dalam produk ini adalah pegadaian akan memberikan ganti kerugian apabila barang jaminan yang berada dalam penguasaan pegadaian mengalami kerusakan atau hilang yang tidak disebabkan oleh suatu bencana alam (force majeure) jang ditetapkan pemerintah. Ganti rugi diberikan setelah diperhitungkan dengan marhun bih (uang pinjaman) dan mu'nah (biaya) pemeliharaan sesuai ketentuan penggantian yang berlaku di pegadaian. ${ }^{41}$

Ketentuan terkait utang (marhun bih/dain) dalam Fatwa Dewan Syariah Nomor 92/DSN-MUI/IV/2014 pada nomor keempat angka satu dan tiga, disebutkan bahwa:

Ketentuan terkait Utang (marhun bih/dain)

1. Utang boleh dalam bentuk uang dan/atau barang;

\footnotetext{
${ }^{39}$ Dokumentasi, Pegadaian Syariah Cabang Palu Plasa, Kantor. (13 Maret 2020)

${ }^{40}$ Lihat ketentuan terkait barang jaminan (marhun) nomor ketiga angka tiga pada Fatwa DSN-MUI Nomor: 92/DSN-MUI/IV/2014 tentang Pembiayaan yang Disertai Rahn, Situs Resmi DSN-MUI, 5. https://dsnmui.or.id/kategori/fatwa/page/5/ (13 Maret 2020)

${ }^{41}$ Dokumentasi, Pegadaian Syariah Cabang Palu Plasa, Kantor. (13 Maret 2020)
} 
3. Utang harus jelas jumlah (kuantitas) dan/atau kualitasnya serta jangka waktunya, ${ }^{42}$

Penerapan ketentuan fatwa ini dalam praktek di Pegadaian Syariah adalah pihak nasabah menyatakan telah berutang kepada pegadaian dan berkewajiban untuk membayar marhun bih (uang pinjaman). Maksud dari kalimat tersebut, pihak nasabah telah menerima beberapan uang pinjaman setelah nasabah menjaminkan atau menggadaikan barang jaminannya kepada pihak pegadaian. Dan kemudian jangka waktu akad maksimum 120 (seratus dua puluh) hari pinjaman (akad) dapat dilunasi atau diperpanjang (ulang rahn), mengangsur marhun bih (uang pinjaman) dan minta tambah marhun bih (uang pinjaman) sebelum dan/atau sampai jatuh tempo. ${ }^{43}$

Selanjutnya dalam ketentuan terkait utang (marhun bih/dain) nomor keempat angka empat pada Fatwa Dewan Syariah Nomor 92/DSN-MUI/IV/2014 disebutkan bahwa utang tidak boleh bertambah karena perpanjangan jangka waktu pembayaran. ${ }^{44}$ Jadi, penerapan ketentuan fatwa ini dalam produk rahn disebutkan apabila terjadi perpanjangan pinjaman (akad) untuk tanggal jatuh tempo, tanggal lelang, besaran marhun bih (uang pinjaman), besaran mu'nah (biaya) akad, dan rincian marhun (barang jaminan), tercantum dalam nota transaksi (struk). ${ }^{45}$

Ketentuan terkait akad pada nomor kelima angka satu dalam Fatwa Dewan Syariah Nasional Nomor 92/DSN-MUI/IV/IV/2014 disebutkan bahwa ketentuan terkait akad pada prinsipnya, akad rahn

${ }^{42}$ Lihat ketentuan terkait utang (marhun bih/dain) nomor keempat angka satu dan tiga pada Fatwa DSN-MUI Nomor: 92/DSN-MUI/IV/2014 tentang Pembiayaan yang Disertai Rahn, Situs Resmi DSN-MUI, 5. https://dsnmui.or.id/kategori/fatwa/page/5/ (13 Maret 2020)

${ }^{43}$ Dokumentasi, Pegadaian Syariah Cabang Palu Plasa, Kantor. (13 Maret 2020)

${ }^{44}$ Lihat ketentuan terkait utang (marhun bih/dain) nomor keempat angka empat pada Fatwa DSN-MUI Nomor: 92/DSN-MUI/IV/2014 tentang Pembiayaan yang Disertai Rahn, Situs Resmi DSN-MUI, 5. https://dsnmui.or.id/kategori/fatwa/page/5/ (13 Maret 2020)

${ }^{45}$ Dokumentasi, Pegadaian Syariah Cabang Palu Plasa, Kantor. (13 Maret 2020) 
dibolehkan hanya atas utang-piutang (al-dain) yang antara lain timbul karena akad qardh. ${ }^{46}$ Utang-piutang yang dimaksud timbul karena akad qardh adalah pinjaman yang diberikan kepada nasabah yang memerlukan dan nasabah wajib mengembalikan jumlah pokok yang diterima pada waktu yang telah disepakati bersama. ${ }^{47}$ Penerapan fatwa dalam Pegadaian Syariah pada produk ini yakni nasabah menerima dan setuju terhadap uraian barang jaminan, penetapan besarnya taksiran marhun (barang jaminan), marhun bih (uang pinjaman), tarif mu'nah (biaya) pemeliharaan, mu'nah (biaya) akad, biaya pemeliharaan marhun (barang jaminan) dalam proses lelang (jika ada), biaya proses lelang (jika ada), bea lelang sebagaimana dimaksud pada Surat Bukti Rahn (SBR) atau nota transaksi sebagai tanda bukti yang sah penerimaan marhun bih(uang pinjaman) dan uang kelebihan lelang (jika ada). ${ }^{48}$

Ketentuan terkait akad pada nomor kelima angka tiga (poin a) dalam Fatwa Dewan Syariah Nasional Nomor 92/DSNMUI/IV/IV/2014 disebutkan bahwa:

Ketentuan terkait Akad

Barang jaminan (marhun) dalam akad amanah hanya dapat dieksekusi apabila pemegang amanah al-Amin, antara lain syarik, mudharib, dan musta'jir) melakukan perbuatan moral hazard, yaitu:

a. Ta'addi (ifrath), yaitu melakukan sesuatu yang tidak boleh/tidak semestinya dilakukan; ${ }^{49}$

${ }^{46}$ Lihat ketentuan terkait akad nomor kelima angka satu pada Fatwa DSNMUI Nomor: 92/DSN-MUI/IV/2014 tentang Pembiayaan yang Disertai Rahn, Situs Resmi DSN-MUI, 5. https://dsnmui.or.id/kategori/fatwa/page/5/ (13 Maret 2020)

${ }^{47}$ Lihat ketentuan umum al-qardh nomor pertama angka satu dan dua pada Fatwa DSN-MUI Nomor: 19/DSN-MUI/IV/2001 tentang al-Qardh, Situs Resmi DSN-MUI, 5. https://dsnmui.or.id/kategori/fatwa/page/2/ (13 Maret 2020)

${ }^{48}$ Dokumentasi, Pegadaian Syariah Cabang Palu Plasa, Kantor. (13 Maret

${ }^{49}$ Lihat ketentuan terkait akad, nomor kelima angka tiga (poin a) pada Fatwa DSN-MUI Nomor: 92/DSN-MUI/IV/2014 tentang Pembiayaan yang 
Implementasi ketentuan fatwa ini dalam praktik di Pegadaian Syariah adalah nasabah menyatakan tunduk dan mengikuti segala peraturan yang berlaku di pegadaian sepanjang ketentuan yang menyangkut utang piutang dengan akad rahn. ${ }^{50}$

Fatwa Nomor 92/DSN-MUI/IV/2014 tentang pembiayaan yang disertai rahn pada nomor keenam angka tiga bahwa dalam hal rahn (dain/marhun bih) terjadi karena peminjaman uang (akad qardh), maka pendapatan murtahin hanya berasal dari mu'nah (jasa pemeliharaan/penjagaan) atas marhun yang besarnya harus ditetapkan pada saat akad sebagaimana ujrah dalam akad ijarah. ${ }^{51}$ Maka, penerapan ketentuan fatwa dalam produk ini adalah marhun (barang jaminan) yang telah dilunasi dan belum diambil oleh nasabah, terhitung sejak tanggal pelunasan sampai dengan sepuluh hari, tidak dikenakan jasa penitipan. Bila melebihi sepuluh hari dari tanggal pelunasan marhun (barang jaminan) tetap belum diambil, maka nasabah sepakat dikenakan jasa penitipan. Besaran jasa penitipan sesuai ketentuan yang berlaku di pegadaian atau sebesar yang tercantum di nota transaksi (struk). ${ }^{52}$

Fatwa Nomor 92/DSN-MUI/IV/2014 tentang pembiayaan yang disertai rahn pada nomor ketujuh angka satu bahwa akad rahn berakhir apabila Rahin melunasi utangnya atau menyelesaikan kewajibannya dan Murtahin mengembalikan marhun kepada rahin. ${ }^{53}$

$\begin{array}{lllll}\text { Disertai Rahn, } & \text { Situs }\end{array}$ https://dsnmui.or.id/kategori/fatwa/page/6/ (13 Maret 2020) 2020)

${ }^{50}$ Dokumentasi, Pegadaian Syariah Cabang Palu Plasa, Kantor. (13 Maret

${ }^{51}$ Lihat ketentuan terkait pendapatan murtahin, nomor keenam angka pada Fatwa DSN-MUI Nomor: 92/DSN-MUI/IV/2014 tentang Pembiayaan yang Disertai Rahn, Situs Resmi DSN-MUI, 6. https://dsnmui.or.id/kategori/fatwa/page/6/ (13 Maret 2020)

${ }^{52}$ Dokumentasi, Pegadaian Syariah Cabang Palu Plasa, Kantor. (13 Maret 2020)

${ }^{53}$ Lihat ketentuan terkait penyelesaian akad rahn, nomor ketujuh angka satu pada Fatwa DSN-MUI Nomor: 92/DSN-MUI/IV/2014 tentang Pembiayaan yang Disertai Rahn, Situs Resmi DSN-MUI, 6. https://dsnmui.or.id/kategori/fatwa/page/6/ (13 Maret 2020) 
Maka ketentuan fatwa ini jika diimplementasikan dalam praktik di pegadaian khususnya pada produk ini adalah nasabah dibatasi dengan jangka waktu sampai akad maksimum 120 (seratus dua puluh) hari pinjaman (akad) dapat dilunasi atau diperpanjang (ulang rahn), mengangsur marhun bih (uang pinjaman) dan minta tambah marhun bih (uang pinjaman) sebelum dan/atau sampai jatuh tempo. ${ }^{54}$

Ketentuan terkait penyelesaian akad rahn nomor ketujuh angka dua dalam Fatwa Dewan Syariah Nasional Nomor 92/DSNMUI/IV/2014 disebutkan, bahwa dalam hal rahin tidak melunasi utangnya atau tidak menyelesaikan kewajibannya pada waktu yang telah disepakati, maka murtahin wajib mengingatkan/ memberitahukan tentang kewajibannya. ${ }^{55}$ Maka penerapan dalam Pegadaian Syariah khususnya produk ini adalah pihak pegadaian mempunyai kewajiban untuk menghubungi nasabah dalam bentuk surat peringatan. Surat peringatan ini bertujuan untuk mengingatkan nasabah agar menyelesaikan kewajiban membayar angsuran sesuai waktu yang sudah disepakati bersama. ${ }^{56}$

Ketentuan terkait penyelesaian akad rahn nomor ketujuh angka tiga (poin a) dalam Fatwa Dewan Syariah Nasional Nomor 92/DSN-MUI/IV/2014 disebutkan, bahwa:

Setelah dilakukan pemberitahuan/peringatan, dengan memperhatikan asas keadilan dan kemanfaatan pihak-pihak, Murtahin boleh melakukan hal-hal berikut:

a. Menjual paksa barang jaminan (marhun) sebagaimana diatur dalam substansi fatwa DSN-MUI Nomor: 25/DSNMUI/III/2002 tentang Rahn (ketentuan ketiga angka 5); ${ }^{57}$

\footnotetext{
${ }^{54}$ Dokumentasi, Pegadaian Syariah Cabang Palu Plasa, Kantor. (13 Maret 2020)

${ }^{55}$ Lihat ketentuan terkait penyelesaian akad rahn, nomor ketujuh angka dua pada Fatwa DSN-MUI Nomor: 92/DSN-MUI/IV/2014 tentang Pembiayaan yang Disertai Rahn, Situs Resmi DSN-MUI, 6. https://dsnmui.or.id/kategori/fatwa/page/6/ (13 Maret 2020)

${ }^{56}$ Dokumentasi, Pegadaian Syariah Cabang Palu Plasa, Kantor. (13 Maret 2020)

${ }^{57}$ Lihat ketentuan terkait penyelesaian akad rahn, nomor ketujuh angka tiga (poin a) pada Fatwa DSN-MUI Nomor: 92/DSN-MUI/IV/2014 tentang
} 
Disebutkan di dalam fatwa DSN-MUI Nomor: 25/DSNMUI/III/2002 tentang rahn (ketentuan ketiga angka 5), bahwa hasil penjualan marhun digunakan untuk melunasi utang, biaya pemeliharaan dan penyimpanan yang belum dibayar serta biaya penjualan. ${ }^{58}$ Maka penerapannya adalah nasabah dapat memberikan kuasa kepada pegadaian untuk menjualkan barang jaminan yang telah jatuh tempo. Apabila nilai penjualan barang jaminan dapat memenuhi kewajiban nasabah kepada pegadaian. ${ }^{59}$

Fatwa Dewan Syariah Nasional Nomor 92/DSNMUI/IV/2014 nomor kedelapan disebutkan, bahwa:

Jika salah satu pihak tidak menunaikan kewajibannya atau jika terjadi perselisihan di antara para pihak, maka penyelesaiannya dilakukan melalui lembaga penyelesaian sengketa berdasarkan syariah setelah tidak tercapai kesepakatan melalui musyawarah. ${ }^{60}$

Implementasi ketentuan fatwa ini dalam Pegadaian Syariah adalah apabila terjadi perselisihan di kemudian hari akan diselesaikan secara musyawarah untuk mufakat dan apabila tidak tercapai kesepakatan akan diselesaikan melalui Pengadilan Agama setempat. $^{61}$

\section{Kesimpulan}

Dari uraian di atas, maka dapat diambil kesimpulan bahwa impelementasi yang ditinjau pada aturan Fatwa Dewan Syariah

Pembiayaan yang Disertai Rahn, Situs Resmi DSN-MUI, 7. https://dsnmui.or.id/kategori/fatwa/page/7/ (06 Februari 2020)

${ }^{58}$ Lihat ketentuan umum ketentuan tiga angka lima pada Fatwa DSN-MUI Nomor: 25/DSN-MUI/III/2002 tentang Rahn, Situs Resmi DSN-MUI, 3. https://dsnmui.or.id/kategori/fatwa/page/3/ (03 Februari 2020)

${ }^{59}$ Dokumentasi, Pegadaian Syariah Cabang Palu Plasa, Kantor. (13 Maret 2020)

${ }^{60}$ Lihat nomor kedelapan pada Fatwa DSN-MUI Nomor: 92/DSNMUI/IV/2014 tentang Pembiayaan yang Disertai Rahn, Situs Resmi DSN-MUI, 7. https://dsnmui.or.id/kategori/fatwa/page/7/ (03 Februari 2020)

${ }^{61}$ Dokumentasi, Pegadaian Syariah Cabang Palu Plasa, Kantor. (13 Maret 2020) 
Nasional Majelis Ulama Indonesia (DSN-MUI) Nomor. 92/DSNMUI/IV/2014 telah menetapkan bahwa fatwa tentang Pembiayaan yang Disertai Rahn dalam semua bentuk pembiayaan atau penyaluran dana Lembaga Keuangan Syariah (LKS) boleh dijamin dengan agunan (rahn) sesuai dengan beberapa ketentuan dalam fatwa tersebut. Jadi, pembiayaan pada produk rahn yang dijalankan oleh Pegadaian Syariah Cabang Palu Plasa telah memenuhi ketentuan-ketentuan dalam fatwa tersebut. Implementasi fatwa ini pun disesuaikan dengan memperhatikan prosedur pembiayaan yang disertai rahn telah disesuaikan dengan alur model bisnis dari masingmasing produk pada Pegadaian Syariah Cabang Palu Plasa. Baik prosedur pada model bisnis dari pembiayaan produk rahn.

\section{Daftar Pustaka}

A. Hipan, Reni, Karyawan Pegadaian Syariah Cabang Palu Plasa, wawancara, Pegadaian Syariah Cabang Palu Plasa: Palu. (02 Januari 2020)

Anshori, Abdul Ghofur, Gadai Syariah di Indonesia (Konsep, Implementasi, dan institusionalisasi), Cet. 1, Yogyakarta: Gadjah Mada University Press, 2006.

Dewan Syariah Nasional Majelis Ulama Indonesia, “Fatwa DSNMUI Nomor: 04/DSN-MUI/IV/2000 Tentang Murabahah", Situs Resmi DSN-MUI, https://dsnmui.or.id/kategori/ fatwa/page/ (17 Februari 2020).

Dewan Syariah Nasional Majelis Ulama Indonesia, “ Fatwa DSNMUI Nomor: 19/DSN-MUI/IV/2001 Tentang Al-Qardh ", Situs Resmi DSN-MUI, https://dsnmui.or.id/kategori /fatwa/page/ (13 Maret 2020).

Dewan Syariah Nasional Majelis Ulama Indonesia, “Fatwa DSNMUI Nomor: 25/DSN-MUI/III/2002 Tentang Rahn", Situs Resmi DSN-MUI, https: // dsnmui.or.id / kategori/fatwa/page/ (13 Maret 2020). 
Dewan Syariah Nasional Majelis Ulama Indonesia, “ Fatwa DSNMUI Nomor: 92/DSN-MUI/IV/2014 Tentang Pembiayaan yang Disertai Rahn ", Situs Resmi DSN-MUI, https://dsnmui.or.id/kategori/fatwa/page/ (15 Oktober 2019).

Dewan Syariah Nasional Majelis Ulama Indonesia, “ Peraturan Organisasi Majelis Ulama Indonesia Nomor: Kep407/MUI/IV/2016 tentang Anggaran Dasar dan Anggaran Rumah Tangga Dewan Syariah Nasional-Majelis Ulama Indonesia ", Situs Resmi DSN-MUI, https://dsnmui.or.id/kami/ad-art-dsn-mui/. $\quad$ (Diakses 15 Oktober 2019)

Dokumentasi, Pegadaian Syariah Cabang Palu Plasa, Kantor Pegadaian Syariah Cabang Palu Plasa.

Fariani, Andi, Urgensi Fatwa MUI dalam Pembangunan Sistem Hukum Ekonomi Islam di Indonesia, vol. 12. no. 1, Jakarta: AlIhkam, 2017. http://ejournal.stainpamekasan.ac.id/index.php/ alihkam/article/view/1191/951. (16 Oktober 2019).

Ghazaly, Abdul Rahman, Ghufron Ihsan, dan Sapiudin Shidiq, Fiqh Muamalat, Cet. 4, Jakarta: Prenadamedia Group, 2015.

Hasan, Abdul Halim, Tafsir Al-Ahkam, Cet. 1, Jakarta: Kencana, 2006.

Ihtiar, Habib Wakidatul, Analisis Fatwa Dewan Syariah Nasional Nomor: 92/DSN-MUI/IV/2014 tentang Pembiayaan yang Disertai Rahn, vol. 03, no.1, Tulungagung: An-nisbah, 2016. http://ejournal.iaintulungagung.ac.id/index.php/nisbah/article/view/274/210 (01 Agustus 2019).

M.Fauzan, Kompilasi Hukum Ekonomi Syariah, Cet. 2, Jakarta: Kencana, 2017.

Mardani, Fiqh Ekonomi Syariah: Fiqh Muamalah, Cet. 1, Jakarta: Prenada Media Group, 2012. 
Muhamad, ed. 1, Metodologi Penelitian Ekonomi Islam: Pendekatan Kuantitatif (Dilengkapi dengan Contoh-contoh Aplikasi: Proposal Penelitian dan Laporannya), Jakarta: PT Rajagrafindo Persada, 2008.

Mustofa, Imam, Fiqih Mu'amalah Kontemporer, Cet. 1, Kota Depok: PT Rajagrafindo Persada, 2016.

Nugroho, Alfian Handina, , Ratna Puspitasari, Euis Puspitasari, Implementasi Gemar Membaca Melalui Program Pojok Baca dalam Mata Pelajaran IPS pada Siswa Kelas VIII di SMPN 2 Sumber, vol. 5, no. 2, Cirebon: Jurnal Edueksos, 2016. http: II www.syekhnurjati.ac.id /jurnal /index.php /edueksos/article/view/1167/846. (23 September 2019)

Nur Iman Sari, Amik Amalia, Pembiayaan Murabahah Disertai Jaminan Perspektif Fatwa DSN-MUI No. 92/DSNMUI/IV/2014 (Studi Kasus di BMT Istiqomah Unit II Plosokandang Kedungwaru Tulungagung), Skripsi, Kabupaten Tulungagung: IAIN Tulungagung, 2017. http://repo.iain-tulungagung.ac.id/5837/ (01 Agustus 2019)

Octavian, Rezki, Karyawan Pegadaian Syariah Cabang Palu Plasa, wawancara, Pegadaian Syariah Cabang Palu Plasa: Palu. (06 Januari 2020)

Pegadaian Syariah Cabang Sei Panas Batam, "Gambaran Umum Kegiatan Usaha Pegadaian Syariah ", Official Website Pegadaian Syariah Cabang Sei Panas Batam. http://ulgs.tripod.com./ aboutme.htm. (20 September 2019)

Rianto Al-Arif, Muhammad Nur, Lembaga Keuangan Syariah (Suatu Kajian Teoretis Praktis), Cet. 2, Bandung: CV Pustaka Setia, 2017.

Shidiq, Sapiudin, Fikih Kontemporer, Cet. 2, Jakarta: Kencana, 2017. 
Sholahuddin, Muhammad, Lembaga Keuangan dan Ekonomi Islam, Katalog dalam Terbitan, Yogyakarta: Penerbit Ombak, 2014.

Smith, Huston, Ensiklopedi Islam (Ringkas), Cet. 2, Jakarta: PT Rajagrafindo Persada, 2002.

Soemitra, Andri, Bank dan Lembaga Keuangan Syariah, Cet. 7, Jakarta: Kencana, 2017.

Sugiyono, ed. 3, Metode Penelitian Bisnis (Pendekatan Kuantitatif, Kualitatif, Kombinasi, dan R\&D), Bandung: Alfabeta, 2018.

Suryabrata, Sumadi, Metodologi Penelitian, Cet. 23, Jakarta: PT Rajagrafindo Persada, 2012.

Toriquddin, Mohamad, Teori Maqâshid Syarî'ah Perspektif AlSyatibi, vol. 06, no.1, Malang: Jurnal Syariah dan Hukum, $2014 . \quad$ http://ejournal.uin-malang.ac.id /index.php/syariah/article/view/3190/5031. (19 September 2019).

Yupiter, Nurul Huda, Hendri Tanjung, Integrasi Akad Pembiayaan dan Akad Rahn: Analisis Kritis terhadap Implementasi Fatwa DSN No. 92 Tahun 2014 pada PT. Pegadaian, Jakarta, vol. 4, no. 1, Jakarta: Al-falah (Journal of Islamic Economic), 2019. https : // garuda . ristekdikti. go .id / documents/detail/1041077. (16 Oktober 2019). 